\title{
PENGEMBANGAN BATIK BERMOTIF LOCAL WISDOM DALAM UPAYA PENINGKATAN PENDAPATAN MASYARAKAT DI KABUPATEN NGAWI
}

\author{
DEVELOPMENT OF BATIK LOCAL WISDOM MOTIVATED IN EFFORTS \\ TO INCREASE COMMUNITY INCOME IN NGAWI DISTRICT
}

\author{
${ }^{1)}$ Nurul Istiqomah, ${ }^{2)}$ Izza Mafruhah, ${ }^{3)}$ Nunung Sri Mulyani, \\ ${ }^{4)}$ Dewi Ismoyowati, ${ }^{5}$ Kresno Sarosa \\ ${ }^{1,2,3,4,5)}$ Fakultas Ekonomi dan Bisnis \\ Universitas Sebelas Maret
}

Email: nurulistiqomah_fe@staff.uns.ac.id

\begin{abstract}
ABSTRAK
Batik merupakan salah satu warisan budaya bangsa Indonesia yang telah ditetapkan oleh UNESCO. Maka tiap daerah dipacu untuk mengembangkan batik sesuai dengan kearifan lokal dan keunikan budayanya. Ngawi belum mempunyai batik dengan ciri khas, sehingga agak sulit untuk membedakan batik produksi Ngawi atau daerah di sekitarnya seperti batik dari Sragen atau Magetan. Oleh karena itu, diperlukan pengembangan batik dengan ciri khas Ngawi berdasarkan kekayaanlokal serta warisan budaya sehingga akan menarik dan mendorong peningkatan permintaan pasar serta pendapatan masyarakat khususnya UMKM yang bergerak di bidang Batik. Pengabdian ini dilaksanakan di Ngawi dan bertujuan :1) Menggali motif khas batik Ngawi dengan memperhatikan kekayaan alam dan budaya 2). Mengenalkan model baru produkdi batik yang mengkolaborasikan antara batik tulis dan print dengan metode malam dingin3) meningkatkan pemasaran dengan pembuatan web dan instragram batik Ngawi. Metode yang digunakan pada pengabdian ini adalah : 1). Focus Group Discussion dengan beberapa stakeholder mengenai kekayaan budaya, sejarah dan alam di Ngawi yang melibatkan pelaku UMKM batik sehingga bisa memberikan konsep mengenai motif batik yang lebih bisa diterima oleh masyarakat luas, dan 2). Pelatihan, mendemonstrasikan membatik dengan teknik malam dingin kepada mitra UKM batik supaya pengetahuannya semakin bertambah dan mempersingkat proses membatik. Hasil dari pengabdian ini adalah diperolehnya desain motif batik khas Ngawi dengan berdasarkan ada kekayaan alam dan budaya yang ada di Ngawi yaitu motif Benteng Van Den Bosch/ Benteng Pendem yang dikolaborasikan dengan motif pohon bambu, daun jati serta motif Trinil yang merupakan salah satu aset terbesar di Ngawi, serta motif Waduk Pondok yang merupakan slah satu kekayaan ekologi yang dimiliki Ngawi. UKM mitra pengabdian juga mendapatkan pengetahuan dan ketrampilan terbaru dalam proses membatik dengan menggunakan metode malam dingin, yang proses pembatikkannya menjadi lebih cepat karena membutuhkan waktu \pm 2 motif untuk proses pembuatan motif sehingga menghemat ongkos produksi. Screen batik yang digunakan dalam proses membatik dengan malam dingin bisa digunakan sampai dengan 1.000 lembar batik. Meningkatnya pemasaran batik ngawi dengan media online.
\end{abstract}

Kata kunci: Batik; Kearifan Lokal; Motif; Malam Dingin

\begin{abstract}
Batik is one of Indonesia's cultural heritages that has been recognized by UNESCO. Each region is encouraged to develop batik in accordance with local wisdom and cultural uniqueness. Ngawi does not yet have batik with its characteristics, so it is difficult to distinguish Ngawi's original batik from that from the neighboring areas such as Sragen and Magetan. Therefore, Ngawi's distinctive batik needs to be developed based on local cultural wealth and heritage to attract tourist interest and encourage increased market demand and community income, especially MSMEs involved in batik production. This community service program was carried out in Ngawi and aimed to: 1) explore the unique motifs of Ngawi batik by observing the natural and cultural riches, 2) introducea new technique in batik production that combines handwriting and printingusing the cold wax, 3) increase marketing by dedicated website and Instagram accountcreation. The methods used in this service program were: 1). Focus Group Discussion, with several stakeholders on the cultural, historical and natural wealth in Ngawi involving batik MSMEs to identify the concept of a batik motif that can be accepted by the wider community, and 2). Training, by demonstrating a batik creation technique with cold wax to batik MSME partners to enrich their knowledge and shorten the batik creation process. This community service program produced
\end{abstract}


Ngawi batik motif designs based on the local natural and cultural richness, namely the Van Den Bosch port (buried port) motif blended with motifs of bamboo trees, teak leaves, Trinil-one of the biggest assets in Ngawi-, and Pondok Reservoir-one of the ecological assets owned by Ngawi. MSME partners of this service program also received the latest knowledge and learned new skills in the process of batik creation with the cold wax method, which is able to accelerate the creation process because it takes \pm 2 motives for the process of making motifs thus reducing the production cost. The batik screen used in the cold wax creation process can be used for up to 1,000 pieces of batik cloth. In addition, Ngawi batik marketing with online media is found to be increasing.

Keywords: Batik; Local Wisdom; Motives; Potential

Submitted : 26 Januari 2019 Revision : 1 Oktober 2019 Accepted : 17 Februari 2020

\section{PENDAHULUAN}

Kabupaten Ngawi saat ini mulai melaksanakan strategi dan komitmen dalam mendorong penguatan sistem inovasi daerah, salah satu yang dilakukan adalah penguatan kluster industri batik. Batik merupakan salah satu warisan budaya bangsa Indonesia yang telah ditetapkan oleh United Nations Educational, Scientific, and Cultural Organization. Istilah United Nations Educational, Scientific, and Cultural Organization (UNESCO). Sejalan dengan itu maka tiap daerah dipacu untuk mengembangkan batik sesuai dengan kearifan lokal dan keunikan budaya masing-masing daerah. Berdasarkan penelitian Apriliani (2016) mengenai Perancangan Motif Batik di Ngawi, menyatakan bahwa di Ngawi untuk pengembangan motif batik Ngawi kurang mendapatkan antusias baik dari masyarakat atau pelaku UKM batik. Selama ini, Ngawi hanya mempunyai batik dengan ciri khas daerah yaitu motif bambu dimana motif bamboo ini juga sudah banyak dimiliki oleh motif batik daerah lain, motif padi, pohon jati, manusia purba dan kali tumpuk. Motif-motif yang selama ini dikembangkan di Ngawi hanya berdasarkan kepada potensi alam saja, tetapi belum banyak mengembangkan potensi seni budaya yang ternyatan sangat kaya dimiliki oleh Ngawi.

Nuriya (2016) menganalisis mengenai Pengaruh Perkembangan Industri Batik Tulis terhadap Motif Melestarikan Budaya di daerah Pati. Berdasarkan hasil penelitian diperoleh hasil bahwa terdapat pengaruh perkembangan industri batik tulis dengan motif untuk melestarikan budaya. Beberapa factor yang mendukung perkembangan industri batik adalah tenaga kerja, pemerintah, dukungan masyarakat, kualitas produksi, dan kuantitas produksi yang mendorong masyarakat untuk melestarikan budaya.Selain itu, pengembangan batik dengan ciri khas tertentu yang menarik akan mendorong peningkatan permintaan pasar dan pada akhirnya akan meningkatkan pendapatan masyarakat khususnya UMKM yang bergerak di bidang Batik.Berdasarkan kekayaan local yang dimiliki oleh Ngawi, maka terdapat beberapa ciri khas yang dapat diusung, yaitu padi, bambu , Benteng Van Den Bosch atau lebih dikenal dengan Benteng Pendem dan Trinil yang menggambarkan manusia purba yang diketemukan di Ngawi.

Perkembangan UMKM Batik di Kabupaten Ngawi selalu mengalami peningkatan, hal ini dapat dilihat dari tabel di bawah ini : 
Tabel 1. Data Perkembangan UMKM Batik di Ngawi

\begin{tabular}{|c|c|c|l|l|}
\hline \multirow{2}{*}{ THN } & \multicolumn{3}{|c|}{ INDIKATOR } \\
\cline { 2 - 5 } & $\begin{array}{c}\text { UNIT } \\
\text { USA } \\
\text { HA }\end{array}$ & $\begin{array}{c}\text { TEN } \\
\text { AGA } \\
\text { KER } \\
\text { JA }\end{array}$ & $\begin{array}{l}\text { NILAI } \\
\text { PRODUKSI }\end{array}$ & $\begin{array}{l}\text { DAERAH } \\
\text { PEMASA } \\
\text { RAN }\end{array}$ \\
\hline 2011 & 9 & 162 & 835.000 .000 & Ngawi \\
\hline 2012 & 11 & 181 & 1.170 .000 .000 & $\begin{array}{l}\text { Jawa } \\
\text { Timur }\end{array}$ \\
\hline 2013 & 16 & 247 & 1.675 .000 .000 & $\begin{array}{l}\text { Jawa } \\
\text { Timur, } \\
\text { Nasional }\end{array}$ \\
\hline 2014 & 19 & 276 & 1.842 .500 .000 & $\begin{array}{l}\text { Jawa } \\
\text { Timur, } \\
\text { Nasional }\end{array}$ \\
\hline
\end{tabular}

Sumber: SIDA Kabupaten Ngawi

Data tersebut menunjukkan bahwa UMKM Batik dari tahun 2011 sampai dengan tahun 2014 telah mengalami perkembangan yang baik, dimana dapat dilihat daerah pemasaran telah keluar dari daerah Ngawi ke beberapa daerah di Jawa Timur. Berdasarkan data tahun 2016, terdapat 115 unit usaha batik, dengan jumlah tenaga kerja sebanyak 196 orang dan nilai investasi yang dikeluarkan mencapai 60 juta rupiah. Adapun kapasitas produksinya sebanyak 4.860 lembar kain batik dengan nilai produksi sebesar Rp. 710,363 juta rupiah.

Batik Ngawi sudah dipasarkan di daerah Ngawi dan diluar Ngawi, namun terdapat beberapa permasalahan yang di keluhkan oleh beberapa UMKM Batik terutama di bidang design dan motif yang tidak terlalu bagus dan pewarnaan yang tidak maksimal. Design dari batik Ngawi masih belum mengalami perkembangan yang sangat signifikan dan masih tertinggal dibandingkan dengan motif batik di sekitarnya, seperti daerah Sragen, Surakarta, dll. Motif batik Ngawi masih menggunakan motif manusia primitive, yang menyebabkan ketertarikan dari calon pembeli dari luar Ngawi masih mempertimbangkan untuk membeli dan mengoleksinya. Oleh karena itu, pada pengabdian kali ini akan mengeksplorasi kekayaan alam dan budaya yang ada di Ngawi untuk dijadikan motif batik khas Ngawi.
Beberapa UMKM Batik di Kabupaten Ngawi salah satunya adalah Enjang Pelangi dan Pringgondani. Kedua UMKM ini merupakan penggerak batik dengan motif khas Ngawi dan serta berhasil untuk menggerakkan masyarakat di sekitar tempat usaha tersebut untuk turut serta melestarikan batik khas Ngawi. Bahan baku yang di gunakan untuk pembuatan batik biasanya di dapatkan dari Kota Solo dan masih menggunakan pewarna batik pada umumnya. Peralatan yang digunakan dalam membuat batik masih sangat sederhana dengan kapasitas kecil mengingat tempat usaha yang masih kecil dan memanfaatkan lahan rumah.

Produsen batik dalam proses produksinya masih melakukannya secara tradisional dan selama ini hanya belajar secara otodidak sehingga menyebabkan jaminan mutu produk yang dihasilkan masih kurang baik dari segi jumlah dan kualitas produknya. Tenaga kerja yang digunakan berasal dari masyarakat sekitar, terutama ibu-ibu rumah tangga yang kadang masih sibuk dengan urusan rumah tangga mereka sehingga hasil dan target waktu yang diberikan jika ada pesanan dalam jumlah banyak tidak bisa terkontrol. Kendala lainnya adalah masih tenaga membatik yang ada di masyarakat belum begitu banyak sehingga produsen mengalami kesulitan jika diberikan tenggat waktu sebentar untuk memenuhi order yang diminta oleh pembeli.

Peningkatan potensi industri batik harus dikembangkan secara sinergis antar seluruh stakeholder terkait baik dari pemerintah, pelaku usaha, akademisi, perbankan maupun masyarakat. Penelitian yang dilakukan oleh Novani et all (2014) tentang peran stakeholder dalam pengembangan cluster batik di Solo menunjukkan bahwa semua pemangku kepentingan dalam kelompok batik solo harus saling bekerja sama untuk menciptakan nilai pengusaha serta nilai pelanggan. Semua pemangku kepentingan dalam komponen layanan industri klaster batik harus mengembangkan kreativitas yang tidak hanya memenuhi kebutuhan pelanggan (biaya rendah) tetapi juga memenuhi seni dan budaya (orisinalitas) batik (kualitas tinggi dan inovasi). Pengusaha harus sering melakukan pelatihan berjalan dengan peralatan yang lebih kompleks, selalu berinovasi produk, mengoptimalkan promosi produk melalui pameran dan internet, 
dan kebutuhan untuk berkelanjutan program pelatihan yang diadakan bekerja sama dengan otoritas pemerintah (Novani, Sarjono, \& Hermawan, 2014).

Tujuan dari pengabdian ini adalah Implementasi Warisan Budaya dalam Pengembangan Industri Batik di Kabupaten Ngawi.

\section{METODE}

Metode pelaksanaan kegiatan pengabdian ini adalah dengan pelatihan mendesain motif batik khas Ngawi yang sesuai dengan kekayaan alam dan budayanya serta memberikan pelatihanmembatik dengan metode malam dingin. Dalam pelatihan tersebut mengundang trainer yang merupakan pengrajin batik yang sudah menggunakan metode tersebut. Pemerintah daerah Kabupaten Ngawi juga sangat mendukung kegiatan pengabdian ini, dengan ikut serta berdiskusi mengenai motif batik yang sesuai dengan kekayaan alam dan buadaya di Ngawi, serta melakukan pendampingan selama proses pelatihan sampai dengan proses produksinya. Beberapa permasalahan, solusi dan metode pengabdian dijelaskanpada tabel berikut ini

Terdapat 2 UKM yang menjadi mitra kegiatan pengabdian adalah pengrajin Batik Pringgondani dan Batik Enjang Pelangi. Batik Pringgondani merupakan salah satu UKM batik Ngawi yang cukup produktif. UKM batik Pringgondani terletak di daerah Mojo, Kecamatan Bringin dan mempunyai showroom untuk memasarkan batik yang dihasilkannya. Mitra pengabdian yang kedua adalah UKM Batik Enjang Pelangi. UKM batik Enjang Pelangi memproduksi batik dengan menggunakan beberapa teknik pembuatan, yaitu dengan metode jumputan, batik cap serta kontemporer. Kedua UKM tersebut mempunyai komitmen untuk mengembangkan batik Ngawi, dan bisa menjadi salah satu pihak untuk mensosialisasikan motif batik khas Ngawi. Selain itu, kedua mitra pengabdian juga masih menggunakan cara yang sederhana untuk memproduksi batiknya. Kedua UKM tersebut juga mempunyai motivasi yang tinggi untuk mengembangkan usahanya serta memberdayakan masyarakat yang ada di sekitar UKM tersebut.

\section{HASIL DAN PEMBAHASAN}

Batik adalah kain tradisional dengan pola unik yang diaplikasikan pada kain menggunakan teknik pewarnaan tahan lilin. Pola batik dibagi menjadi beberapa kelompok desain sesuai kelas template. Setiap kelas memiliki ratusan variasi di dalamnya. Meskipun terdapat kesamaan sehingga polapola batik dapat diidentifikasi, yang dikembangkan berdasarkan fitur tingkat tinggi dari batik yang tidak berubah dalam skala, rotasi, dan transformasi lainnya. Penelitian yang dilakukan oleh Nurhaida et all ( 2015 ) ini memperkenalkan pendekatan untuk pengenalan pola batik menggunakan Fitur Invarian Skala Transform (SIFT) sebagai metode ekstraksi fitur. Hasil penelitian ini dilakukan sebagai upaya mempermudah dalam pemahaman atas pola dan motif batik karena adanya sifat-sifat simetris dan berulang dari pola batik. Hasil penelitian menunjukkan bahwa pada koleksi 120 gambar batik yang dihasilkan dari 20 pola batik dasar (Nurhaida, Noviyanto, Manurung, \& Arymurthy, 2015)

Berdasarkan hasil diskusi dengan stakeholder yang ada di Ngawi, maka diangkat beberapa kekayaan lokal yang dimiliki Ngawi sebagai motif khas Kabupaten Ngawi, yaitu Benteng Van Den Bosch atau yang lebih dikenal dengan Benteng Pendem dan Waduk Pondok. Kedua motif tersebut menambah motif batik khas di Ngawi. Kedua motif tersebut belum pernah diangkat sebagai motif batik yang dibuat di Ngawi. Benteng Van Den Bosch merupakan kekayaan heritage yang dimiliki Ngawi dan daerah lain tidak memilikinya. Motif tersebut dipatenkan sebagai salah satu motif batik khas Ngawi, sehingga batik Ngawi mempunyai tambahan identitas.

Pengabdi bekerja sama dengan pengrajin batik di daerah Sragen yang sudah terlebih dahulu menggunakan metode membatik dengan malam dingin tersebut untuk memberikan pelatihan bagi mitra UKM batik di Ngawi. Kombinasi beberapa potensi kekayaan diantaranya pohon bambu yang sudah lama menjadi motif batik Ngawi, serta hutan jati yang menjadi salah satu asset unggulan di Ngawi didiskusikan untuk melengkapi pola batik khas Ngawi. Berikut ini hasil penggambaran pola batik khas Ngawi yaitu Benteng Van Den Bosch/ Benteng Pendem: 


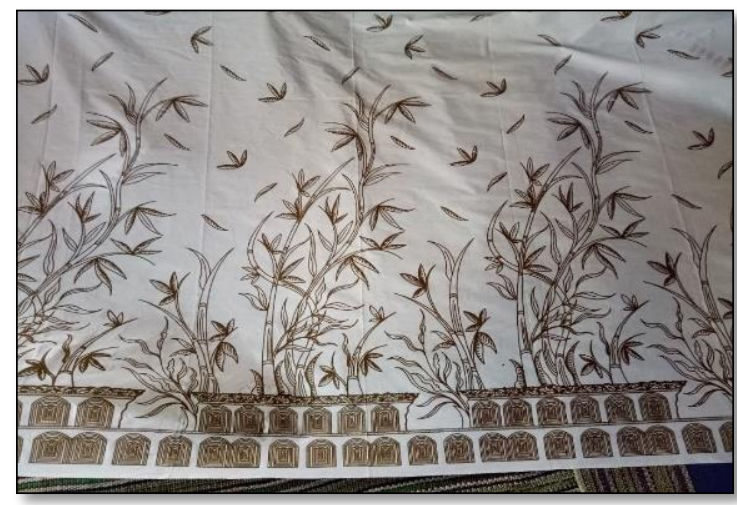

Gambar 1. Motif Benteng Van Den Bosch/Benteng Pendem pada Batik Ngawi

Pembacaan arti dari motif batik khas Ngawi tidak bisa dilihat per bagian, tetapi diartikan secara holistik. Adapun motif batik Ngawi bisa dijabarkan sebagai berikut ini :

1. Bagian bawah melambangkan kekayaan heritage, yaitu Benteng Van Den Bosch/ Benteng Pendem yang tidak dimiliki oleh daerah lain dan gading yang menggambarkan salah satu warisan sejarah di Ngawi.

2. Benteng Pendem yang tergambarkan di pola batik tersebut dibuat dari kambium pohon jati, yang menggambarkan kekokohan dan menggambarkan kekayaan Ecology yang ada di Ngawi.

3. Bagian atas dari Benteng Pendem menggambarkan humus yang ada di Ngawi, yang menggambarkan kesuburan.

4. Kesuburan tanah yang disebabkan karena adanya humus tersebut menimbulkan munculnya padi. Padi merupakan salah satu kekayaan lain dari Ngawi, yaitu Agriculture-nya yang menjadi salah satu lumbung padi organic di Jawa Timur.

5. Motif bambu di Ngawi berbeda dengan motif bambu pada batik Sragen dan Magetan, karena bentuknya lebih langsing dan menjulang ke atas, menunjukkan bahwa Ngawi siap tumbuh. Daun-daun bambu tersebut menyebar ke sekitarnya, yang menunjukkan arti bahwa keberhasilan Ngawi akan menyebar kemana-mana dan memberikan efek yang positif ke daerahdaerah di Ngawi dan sekitarnya.

Proses membatik dengan metode malam dingin berbeda dengan proses membatik yang selama ini menggunakan malam panas, dimana dalam proses membatik, tersebut malam selalu harus dipanaskan dalam tungku kecil dan menggunakan canting. Sedangkan dalam metode malam dingin, menggunakan beberapa bahan yang menjaga supaya malam tersebut tetap cair

Motif yang kedua untuk dikembangkan sesuai dengan potensi Ngawi adalah motif mengenai Waduk Pondok. Waduk Pondok merupakan salah satu kekayaan alam yang dimiliki Kabupaten Ngawi yang menggambarkan asset ekologi yang dimiliki Ngawi. Berikut adalah filosofi dari motif batik Waduk Pondok Ngawi :

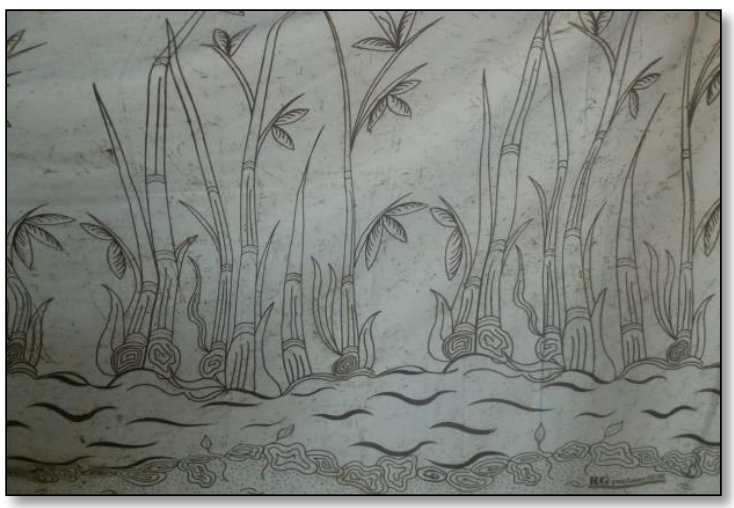

Gambar 2. Motif Waduk Pondok Ngawi

Uraian mengenai motif Waduk Pondok Batik Ngawi adalah sebagai berikut :

1. Pada bagian bawah, terdapat titik-titik putih yang menunjukkan kesuburan tanah di Kabupaten Ngawi.

2. Di atasnya terdapat potongan-potongan dari kayu jati yang terdapat kambiumnya, yang menggambarkan kekayaan Ngawi salah satunya adalah hutan jati dan merupakan daerah yang kokoh.

3. Tunas-tunas yang terdapat di atas potongan kayu jati menggambarkan pertumbuhan di Kabupaten Ngawi yang akan terjadi secara terus menerus.

4. Diatas tunas-tunas tersebut, terdapat air yang menggambarkan salah satu sumber air di Kabupaten Ngawi yaitu Waduk Pondok. Sehingga Ngawi merupakan daerah yang subur dan makmur.

5. Warna putih yang terdapat pada atasnya air menunjukkan gambar gading, yang menggambarkan gading dari mammoth atau gajah purba sebagai intepretasi bahwa 
Ngawi juga memiliki kekayaan sejarah berupa Trinil yaitu warisan dari purbakala.

6. Bambu-bambu yang ada menjulur ke atas, menunjukkan potensi yang ada di Ngawi akan terus berkembang bagus seiring dengan pertumbuhannya yang semakin bagus.

Pola pewarnaan digunakan untuk membuat batik Ngawi semakin terlihat bagus dan bisa memperkuat penggambaran filosofi yang ada di Ngawi tersebut. Motif batik Ngawi dengan tema Waduk Pondok setelah melewati proses pewarnaan semakin memperkaya dan memperkuat batik khas Ngawi.

Tujuan kedua pengabdian ini adalah untuk mengembangkan metode baru dalam peningkatan jumlah produksi batik, mempercepat proses produksi, mengurangi biaya namun tetap dengan kualitas mempertahankan kualitas. Industri batik dibedakan menjadi beberapa jenis, yaitu batik tulis, batik printing, batik cetak dan kain motif batik namun tidak dihasilkan dengan peroses membatik. Batik tulis merupakan keunggulan utama dan banyak diminati oleh masyarakat dan pecinta seni dunia, namun terdapat kendala dalam proses membatik yang memakan waktu lama, mulai dari proses pembuatan motif, menyanting, pewarnaan, pelorodan dan pencucian. Proses paling lama dalam membatik adalah menyanting yang bisa memakan waktu sampai berminggu bahkan berbulan tergantung dari kerumitan motif yang dibuat. Hal ini menyebabkan harga batik tulis menjadi sangat mahal bahkan mencapai jutaan rupiah untuk satu potong kain. Susanti (2016) melakukan penelitian optimalisasi pembatikan yang mencapai penghematan bahan baku sebesar $14,801 \%$ dan menghemat waktu produksi $10,345 \%$ dengan metode particle swarm optimization (PSO). Metode ini dikenalkan sebagai upaya mempercepat proses produksi dan mengeliminir harga batik (Soesanti \& Syahputra, 2016). Kegiatan pengabdian ini menggunakan metode malam dingin, merupakan tehnik baru yang memadukan antara batik tulis dan printing. Malam yang selama ini diaplikasikan dalam bentuk panas yang dicanting pada motif dan pola yang sudah dibuat dengan metode ini dicampur dengan bensin dan didinginkan.
Langkah yang dilakukan secara detail sebagai berikut :

1. Membuat cetakan motif batik dalam screen terbuat dari kaca yang diukir timbul yang di pigura dengan kayu. Lebar screen adalah $2 \mathrm{x}$ 1,3 atau sepanjang kain yang diinginkan. Satu screen bisa diaplikasikan untuk membuat 1000 lembar barik.

2. Menyiapkan meja sebagai landasan pencetakan

3. Siapkan kain yang akan dibatik

4. Kain dijepit erat pada pigura screen

5. Cairkan malam sampai lumer, pada posisi panas, campur dengan bensin kemudian dinginkan

6. Tuang dan ratakan malam yang sudah dingin dengan kayu, proses ini akan memakan waktu 5 sampai 10 menit

7. Angkat pigura, screen dan batik sudah selesai dicetak.

8. Kain yang sudah tercetak diangin-angin agar malam menempel sempurna selama setengah hari

9. Setelah kering maka kain siap untuk dibatik colet dan diwarnai.

10. Pelatihan sudah dilakukan terhadap kelompok UKM dan berjalan dengan baik. Proses ini terbukti mampu meningkatkan jumlah produksi, menekan biaya dan mempersingkat waktu produksi.

\section{SIMPULAN}

Pengabdian yang dilakukan untuk mengembangkan batik di Kabupaten Ngawi di sambut baik oleh dua UMKM Batik yaitu Pringgodani dan Enjang Pelangi. Selama ini, motif batik yang di ajarkan ternyata bisa dijadikan produk unggulannya. Adanya training yang diberikan oleh tim pengabdi membuat motif batik dan cara pebuatan batik yang lebih cepat dapat meningkatkan pendapatan semakin meningkat pula. Motif batik Ngawi dengan mengkaji kekayaan budaya merupakan hasil diskusi antara pengrajin, pemerintah daerah dan tim pengabdi. Maka sebagai bentuk kebanggaan dari tim pengabdi untuk turut serta mengembangkan motif batik khas Ngawi, pada kain batik tersebut maka motif batik khas Ngawi akan di-HAKI-kan. 


\section{DAFTAR PUSTAKA}

Ansor, Yusak dan Kusrianto, A., (2011). Keeksotisan Batik Jawa Timur . Jakarta: Elex Media Koputindo.

Apriliana, I.M., Budiharjo, Hardman dan Karsam. (2016). Perancangan Motif Batik Tulis Ikon Kabupaten Ngawi sebagai Media Promosi dalam Menunjang Industri Kreatif. Art Noeveau, 5 (2).

Djoemena, N. S., (1990). Ungkapan Sehelai Batik: Its Mystery and Meaning. Jakarta: Djambatan.

Hamzuri. (1985). Batik Klasik. Jakarta: Djambatan.

Mafruhah, I., Waridin, W., Iskandar, D. D., \& Thohir, M. (2019). Formulating Post Placement Empowerment of Indonesian Migrant Workers Policy: What are the role of Stakeholders. International Journal Trande and Global Markets, 12(1).

Novani, S., Sarjono, U., \& Hermawan, P. (2014). An Application of Soft System Methodology in Batik Industrial Cluster Solo by using Service System Science Perspective. Procedia - Social and Behavioral Sciences, 115(Iicies 2013), 324-331.

https://doi.org/10.1016/j.sbspro.2014.02.
439

Nurhaida, I., Noviyanto, A., Manurung, R., \& Arymurthy, A. M. (2015). Automatic Indonesian's Batik Pattern Recognition Using SIFT Approach. Procedia Procedia Computer Science, 59(Iccsci), 567-576.

https://doi.org/10.1016/j.procs.2015.07.5 47

Nugroho, E., (2008). Pengenalan Teori Warna. Yogyakarta: Penerbit Andi.

Nurainun, Heriyana, \& Rasyimah. (2008). Analisis Industri Batik di Indonesia. Fokus Ekonomi, 7 (3), 124-135.

Rustan, S., (2009). Mendesain Logo . Jakarta: Gramedia Pustaka Utama.

Soesanti, I., \& Syahputra, R. (2016). Batik Production Process Optimization Using Particle Swarm Optimization Method. Journal of Theoretical and Applied Information Technology, 86(2), 272-278.

Susanti, S., (2015). Analisis Dampak Perekonomian Industri Batik Menggunakan SWOT di Kecamatan Pasar Kliwon Surakarta. Skripsi. Universitas Muhammadiyah Surakarta.

Utoro, B., (1979). Pola-pola Batik dan Pewarnaan.Jakarta : Departemen Pendidikan dan Kebudayaan. 